\title{
Strategic Nonviolence in Africa: Reasons for Its Embrace and Later Abandonment by Nkrumah, Nyerere, and Kaunda
}

\author{
GAIL M. PRESBEY \\ University of Detroit Mercy, Detroit, Michigan, USA
}

\begin{abstract}
Soon after taking power, three leaders of nonviolent African independence movements, Kwame Nkrumah of Ghana, Julius Nyerere of Tanzania, and Kenneth Kaunda of Zambia immediately turned to violent means to suppress internal opposition. The paper examines the reasons for the success of their Gandhian nonviolent tactics in ousting British colonial governments and argues that these new heads of state lost confidence in nonviolence due to a mixture of self-serving expediency, a lack of understanding of nonviolence's many different forms, and the constraints of inheriting a state already dependent on the use of force.
\end{abstract}

\section{Introduction}

The three famous heads of State who led their respective countries from colonial rule to independence-Kwame Nkrumah of Ghana, Julius Kambarage Nyerere of Tanzania, and Kenneth David Kaunda of Zambia - all advocated nonviolent resistance against the colonial powers. Each came to power without having to organize armed resistance against the colonizers. They praised mass nonviolent action for its ability to encourage otherwise superior armed powers to capitulate to their demands and looked forward to leading their countries in a humane and democratic fashion. After taking office, each faced internal dissent or stiff opposition. In such circumstances, and to different degrees, they called upon the coercive power of the Western-style States that they inherited. Each concluded that to rule a country in nonviolent fashion was impossible.

In this paper, I will explore several questions. First, what characteristics of nonviolence make it at first an able tool for those protesting their oppression? Why does maintaining nonviolence become difficult, causing the protestors to resort to coercion and force after gaining the reins of State power? Is this difficulty a sign that nonviolence has limited usefulness, or does it indicate a need to change the structure and behavior of States? Have any authors addressed the issue of what nonviolence from a position of state power would look like?

I will also discuss Nkrumah, Nyerere, and Kaunda's positions on nonviolence and violence. Many whole books already discuss these three figures and their uses of

This is a pdf copy of the author's accepted manuscript version of "Strategic Nonviolence in Africa: Reasons for Its Embrace and Later Abandonment by Nkrumah, Nyerere, and Kaunda," by Gail M. Presbey. The version of record appears in Spiritual and Political Dimensions of Nonviolence and Peace, edited by David Boersema and Katy Gray Brown, Amsterdam: Rodopi, 2006, pp. 75-101. 
violence and nonviolence. This paper, limited in scope, could never do justice if I attempted to pass judgment on the efficacy or morality of their statesmanship. For manageability, I will focus on the time just prior to, and just after they won independence. I will focus on the apparent contradiction that the same men who experienced the efficacy of nonviolence against the British colonial powers in their countries abandoned nonviolence as soon as fellow Africans challenged them in their countries. I will include discussion of interviews with Nyerere and Kaunda found in Guns and Gandhi in Africa: PanAfrican Insights on Nonviolence, Armed Struggle, and Liberation in Africa. ${ }^{1}$ Co-author Bill Sutherland draws upon his first-hand experience as an AfricanAmerican who came to Ghana to work with Nkrumah in the 1950s. He gives us some insights into the troubles and transformations that Nkrumah experienced.

As a background for these three cases, I will briefly compare aspects of colonial rule to pre-colonial governance in Africa, and current Western-based models of democracy. While the European governments that ruled African countries had some amount of representative democracy at home, they ruled their colonies in an authoritarian fashion. The goal of colonial government was efficient administration. They instilled a repressive order to facilitate an economy based on extraction of resources from Africa and marketing of massproduced European goods to Africans. ${ }^{2}$ As historian of Africa Basil Davidson notes, Europeans never had preparing Africans for self-rule as one of the goals of their administration of the colonies. This deficit was a factor in the shaky transition from colonial rule to self-rule. Instead, colonial government provided examples of the use of coercive power - dictatorship — instead of democracy. ${ }^{3}$

Mahmood Mamdani, in his studies of colonial rule in Africa, notes that British colonial powers ruled through "decentralized despotism." Colonists would conquer an area militarily, but strike an agreement with reigning chiefs and kings to let them continue in their positions of local power if they would accept the ultimate authority of the British. They gave local chiefs broad powers to rule in any way they saw fit as long as they turned over the required amount of taxes to the colonial government. Where the British did not find people organized by ethnicity and ruled by a chief, for example in a community self-governed by age sets or in a series of very small communities, they gladly amalgamated people into "tribes" and gave them a "chief"-doing some creative tradition-making. ${ }^{4}$ Striking a deal with local leaders from whom they might otherwise strip of all power appeared to be culturally sensitive but was actually quite manipulative. Peasants more readily accepted the continued rule of their traditional leaders and so did not fight the British directly. If disputes arose, the people usually directed their anger at their local leadership which had to absorb the shocks that came with changes under colonialism.

There was a crucial difference between pre-colonial and colonial rule. In precolonial times, the relationship between the ruler and their people had a series of checks and balances. A chief would consult key parties before making any ruling. An 
emphasis on maintaining community consensus ensured that the leaders would hear legitimate concerns of the community and the people would not be marginalized. People had official channels to dissent from rulings of their leaders. Most communities understood that the chief, while having authority to make decisions, got that authority from the consent of the people. ${ }^{5}$ Were the people to disapprove of the chief and withdraw their consent, the chief could be removed. Once chiefs accepted British authority, their dependence on the consent of those ruled disappeared. A chief could make unpopular rulings and the people would be surprised to find out that the British curtailed their ability to oust the unresponsive chief. For example, if peasants refused to pay their taxes, the chief could call upon the military power of the British to ensure that the tax was collected. Therefore, while the situation might appear similar to the pre-colonial set-up, at the heart of things, there had been a radical change in power relations.

Now, according to theorist on nonviolence Gene Sharp, the people always have the power to topple their government, which draws its power from the consent and cooperation of the governed. Sometimes the people (due to government repression) forget their power and presume that the government is a monolith which monopolizes all power, leaving them powerless. According to Sharp, nonviolent action can succeed when the people realize that they are the source of the dictator's power. By withholding their cooperation, the dictator is rendered helpless. For example, if the people hold the purse strings to their rulers, they could threaten to cut off the ruler's funds by refusing to pay taxes (as Henry David Thoreau suggested). In other situations, civil servants or soldiers could refuse to carry out their orders. ${ }^{6}$

The situation gets more complicated when a foreign government props up a local government, as is the case in colonialism. Local peoples could withdraw support from the local ruler and refuse to cooperate or pay taxes. But if that ruler can call upon reinforcements from the colonizers, the people will still be oppressed. The only way to solve a problem like that is to reach the people of the country doing the repressing - which is what the movement for independence of African countries did. It tried to influence British citizens to pressure their government to be humane and offer colonies independence.

Hannah Arendt has a theory of political action, which explains that power is the product of consent freely given between peers. When people decide to act together in concert, their actions are effective and they are powerful. Echoing Sharp's description of the role of the people in propping up their leaders, Arendt explains that a leader can only be effective when the people support that leader. Arendt insists that the use of violence or coercion is the opposite of power. Rulers resort to violence and coercion when they feel their power slipping. When people no longer cooperate, rulers escalate to using violence. Violence is not a manifestation of power but a sign that power is diminishing. ${ }^{7}$

Arendt's analysis of power-violence dynamics is interesting. Using violence shows some amount of power: loyal troops, ability to gain supplies and hardware 
needed to engage in acts of violence. A truly powerless leader would have no loyal followers to carry out his commands. But a government in trouble could draw upon a stockpile of weapons gained from earlier cooperation even if current subjects refuse to manufacture arms or send new supplies. Arendt's point was that if the ruler were able to convince the people to cooperate, violence would be unnecessary. In this sense, the turn to violence represents a failure.

Violence or coercion can succeed in its aims or not, depending on the reaction of those who bear its brunt. Sometimes victims of violence internalize its message and decide to submit, even changing their minds and deciding to cooperate with the system. At other times, people submit to coercion but internally remain set against the source of violence, vowing to act differently as soon as the coercive power remits. Arendt focuses on the second dynamic. She suggests that such violence will be selfdefeating since it does not change the minds of those for whom violence controls their outer actions. Those who have not been convinced wait for their opportunity to resist and will eventually do so. She notes warily that violence coupled with speech, often in the form of propaganda, can have the effect of convincing people to change their minds - and if so, changing minds and winning over wills helps a ruler who uses violence to regain power. ${ }^{8}$

Taking the foregoing into account, the thesis we will explore is whether Nkrumah, Nyerere, and Kaunda turned to coercion or violence when they felt their power slipping. Having inherited states shaped by colonial powers, they were able to draw upon the means of coercive violence stockpiled there. This resort to violence was part of the colonial model of governing. Bill Sutherland argues that this quandary will lead us to question the structure of the state instead of questioning nonviolence. At closing, we will explore this suggestion of Sutherland's.

We can see another dynamic in Nkrumah, Nyerere, and Kaunda's use of violence. Each begins to use violence and repression as soon he was in the seat of power, a perspective from which it may appear that each was immune to retaliation. The British, with their army, could seem capable of harmful retaliation. Strategically, violence would not easily succeed against them. But those who bore the brunt of repression in the newly independent states were not well armed or organized. "Preventive detention" or outright killing could swiftly crush them. This idea of immunity to the repercussions of violence is, according to the above account of Arendt and Sharp, an illusion. But it is almost an optical illusion to the person in power, for whom the benefits of violence and oppression appear so concrete, with future reprisal a more distant and speculative result. The irony is, as nonviolent activists, each of the three had been hoping to induce some clear vision in the British, who had been in their position not long ago.

\section{Kwame Nkrumah}

During the 1940s, Nkrumah had lived in the United States and England, where he obtained education on a wide range of political theories. He also attended the Fifth 
Pan-African Congress in 1945, from which came a common platform for independence movements based largely on Mahatma Gandhi's recently successful fight for independence in India. The platform held that independence would have to be a broad-based people's movement and that freedom from colonialism, in the form of African socialism, would be won by the means of "positive action" which would refrain from violence. ${ }^{9}$

Gandhi's influence in Ghana also came through Ghanaian soldiers who had fought for Britain during World War II. Housed at a big camp for Commonwealth soldiers in Durban, Geoffrey Adumah explained that Indians in South Africa challenged them, saying, why are you fighting for the freedom of the British if you are not free in Ghana? Why should 5,000 Britons rule over two million Africans? It was there that they heard of Gandhi's nonviolent struggle in India. When the 65,000 ex-Servicemen returned to Ghana, many of them gathered in 1948 to write up and deliver a petition to the Governor, but police fired upon them as they marched to the Governor's residence, and three were killed. In response, people following the marchers returned to Accra and rioted, burning stalls and stores, houses, and European cars. Komla Gbedema explained that the looting was fueled not only by frustration with the police over the shooting, but also by frustration with West African merchants who had been charging high prices in their stores. A nonviolent boycott had already been underway to put pressure on the merchants, but with emotions running high, the stores were attacked. Within a month twenty nine died and 237 were injured. ${ }^{10}$ In such a situation, emphasizing nonviolent discipline was a challenge.

Nkrumah was not alone in trying to combine the insights derived from Karl Marx's critique of capitalism — exposing colonial exploitation — with the non-Marxist idea that the struggle against capitalists could be won without violence. He led a successful positive action campaign during 1950-1951 to pressure Great Britain to grant internal self-rule to Ghana. He described positive action, in speeches and a widely-distributed pamphlet, as comprising strikes, boycotts, and non-cooperation. As Nkrumah later explained, "We had no guns, but even if we had, the circumstances were such that non-violent alternatives were open to us, and it was necessary to try them before resorting to other means." "In this quote Nkrumah shows himself as committed to the tactics of nonviolence, but not spiritually and morally committed to creedal nonviolence in the Gandhian sense.

In Nkrumah's autobiography, we see his uncertainty during his first use of positive action. He had met with Reginald Harry Saloway, the Colonial Secretary, to warn him of the impending action. Saloway argued that positive action would bring chaos and disorder. He charged that Africans could not be as successful as Indians could in using the method because Indians had practice in suffering pain and deprivation (alluding presumably to a tradition of Hindu asceticism) while Africans did not. For example, Gandhi's use of general strike drew heavily on the concept and tradition of "hartal," a day of mourning, familiar to Hindus. ${ }^{12}$ 
Regardless, Nkrumah still called for positive action on 8 January 1950. He called a general strike, suggesting everyone should stay home from work. By 10 January that year, he noticed that enthusiasm was waning and some stores reopened on 11 January. He wondered whether Saloway was right - whether Africans could not muster the discipline for nonviolent action. Fortunately, happy circumstances re-galvanized the movement that day. Walking through town, wondering what he would next do, a crowd began to gather and follow him. Before long, a large crowd gathered in front of the Evening News office. Addressing the people there, he asked everyone to fill Accra arena that evening. His speech at the arena, followed by favorable news coverage, got the movement back on its feet. ${ }^{13}$ Gandhi often emphasized the role of the press in a successful nonviolent action.

That instance of positive action met with challenges. Editors who wrote sympathetic reports were arrested on charges of sedition. During violent outbreaks, provoked by the police, protestors killed two police. The British arrested Nkrumah and charged him with organizing an illegal strike. They reasoned that the purpose of the strike was not to solve a labor dispute but to pressure the government. They tried, unsuccessfully, to hold him accountable for the deaths of the two police officers.

Still, not long after the general strike, the British agreed to internal governance. Nkrumah was elected as Leader of Government Business within the internal selfgovernment. ${ }^{14}$ Sutherland and Meyer describe the use of positive action by Ghanaians as "a phenomenal success for Gandhian strategy." 15 By 1957, Great Britain granted Ghana independence. Nkrumah became Ghana's first president.

Sutherland's first-hand experience with nonviolence goes far back into the 1940s and 1950s when he served a four-year prison sentence for being a conscientious objector after refusing the drafted during the Second World War. He was a co-founder of the Congress of Racial Equality (CORE). During the 1950s, nonviolent activists from abroad, including African Americans like Sutherland and Bayard Rustin, came to Ghana to show support for Nkrumah. They built on the beginnings of the nonviolent movement that had catapulted the president to power in an independent African state. Sutherland was also fleeing McCarthyism in the United States and looking for a place where he could express his political ideas freely. ${ }^{16}$

Sutherland's commitment to nonviolence contrasted with Nkrumah's. Sutherland's actions mirrored developments in nonviolence used in the Civil Rights Movement in the United States. On one occasion, he and Bayard Rustin, among Ghanaians and other Africans, joined the Sahara Protest Team. They went up through northern Ghana to what was then Upper Volta (now Burkina Faso) to protest French nuclear testing in the desert. They intended to blockade the entrance to the facility to draw attention to the ways in which the arms race was continuing in Africa. The Convention People's Party supported their action. Abraham Johannes (“A.J.") Muste was uncomfortable with the official government support of the nonviolent action since he had difficulty believing that any state, including Nkrumah's, was truly devoted to nonviolence. Sutherland explains that Nkrumah supported their efforts because he 
wanted Ghana to be critical of the arms race. At the same time, Nkrumah was moving away from nonviolence as a method. ${ }^{17}$

Encouraged by the success of positive action in the early 1950s, many nonviolent activists had come to Ghana. When Muste, Ralph Abernathy, and others suggested, at a Positive Action Conference in Ghana in 1960, that a Pan-African nonviolence training camp be set up, Africans in attendance thought that these international advisors were dangerously romantic. Sutherland remembers Frantz Fanon giving a very sober and soft-spoken argument about the unfortunate necessity of violence in the cause of liberation.

Afterward, Sutherland received a letter from Nkrumah saying they were going to set up an ideological school in Winneba, Ghana, and that a wing of the school would be devoted to nonviolence training where Sutherland could have a role in teaching. They did build the center at Winneba, but the nonviolence wing never materialized. Sutherland and Meyer bemoan, "The nonviolence advocacy so prominent in the 1958 All-African Peoples Conference, in the 1959 Sahara Protest Teams, and in the planning for the 1960 Positive Action Conference were all but eliminated from the mainstream of political discourse."18

From its beginning, many problems beset the Ghanaian government headed by Nkrumah. Some authors speculate that from the start, the British governor, Arden Clark, negotiated the steps of independence in a way that a neo-colonial pattern was inevitable. In this "battle of wits" Nkrumah failed to beat his experienced opponent.

Marika Sherwood wrote, "Nkrumah was a multilayered man and the world in which he operated was fractious and highly exploitative." ${ }^{\prime 19}$ Under such circumstances, success would be difficult. Nkrumah's exposure to a wide range of political and economic philosophies was a strength, but he could not meld these differing views and influences into a coherent and practical political philosophy and plan of action. ${ }^{20}$

Commentators have often suggested that United States' businesses manipulated Nkrumah into taking out a huge loan to fund the Upper Volta River Dam project, plunging Ghana country into indebtedness. ${ }^{21}$ Nkrumah, who often saw destructive meddling of the United States in every coup attempt across Africa (including the eventual coup against him), never complained about the United States' role in the dam project. To the end, he defended his decision to build the dam as necessary for the economic independence of Ghana and West Africa. ${ }^{22}$

An oft-repeated history of Nkrumah's fall from power cites his increasing repression in the face of threats to his rule. While initially popular due to his funding of education and health care, indebtedness resulted from the projects. A "loyal opposition," comprised of traditional chiefs led by Joseph Kwame Kyeretwi Boakye (J. B.) Danquah, who intended to rule Ghana upon its independence, had always existed in the country. These chiefs felt betrayed by the British when the reins of power were handed over to the young Nationalists-Nkrumah and his Congress 
People's Party. Nkrumah, for his part, did not want the country run by "illiterates" whom he viewed as compromised by their years of cooperation with the colonial forces. $^{23}$

When cocoa prices dropped on the market, compounded by Nkrumah taxing cocoa to fund national development, disgruntlement began in earnest. Nkrumah insists that the farmers, at first, supported the use of cocoa funds for development, but then politicians manipulated them to oppose it. He described the forces that eventually rallied against him as tripartite: local "reactionaries," the chiefs and the foreigneducated middle class; foreign-trained army officers; and the foreign imperialists and neo-colonialists, Britain and the United States. ${ }^{24}$

In response to challenges to his policies, Nkrumah set up a series of increasingly repressive laws. Government could jail people without trial if they were deemed security risks. Beginning in 1961, anyone guilty of insulting Nkrumah could get a three-year prison sentence. In 1961, when a general strike was organized to protest against him (now on the receiving end of positive action), he took command of the armed forces. In 1964, he declared Ghana a one-party state. In his last two years in office, he withdrew into isolation, in great part out of fear of attempts on his life. ${ }^{25} \mathrm{He}$ explained that he was in favor of one-party states only when the one party was committed to socialism, since a socialist party would be committed to "the will of the masses working for the ultimate good and welfare of the people as a whole" instead of to one class or another as in the two-party British system. He would be against oneparty states run by neo-colonialists or tyrants. From his perspective, controlling multiple parties, which might break up along religious or ethnic lines, was a necessary measure in a time of national emergency when the security of the State was at stake. At first forcing all opposition groups to merge into one, he later tired of the "disunity" and "confusion" stirred up by the opposition party and banned it in $1964 .{ }^{26}$

Arguably, this pattern of increasing coercive measures was a sign, not of increased power, but of his losing power as Arendt describes. To be sure, Nkrumah was up against formidable opponents and his opponents were able to use the media to win people's minds and cooperation away from his policies. Ghana gained its independence during the Cold War when superpowers fought over spheres of influence in ways that could turn smaller African countries into political footballs. Regardless, while the coup-plotters did use some violence to attain their goal, to an extent, as Gene Sharp's theory would predict, their job was easier because people no longer wanted to stand in solidarity with Nkrumah. He recounts with bitterness how his most trusted aides quickly abandoned him upon news of the coup. In such a context, retaining power was exceedingly difficult.

Nkrumah does not admit that the coup against him had popular support. He argues instead that his officers did not fight but capitulated because they were surprised with a fait accompli. He also argues that many officers of the armed forces were Britishtrained and unduly susceptible to British propaganda claiming that he was a dictator. ${ }^{27}$ 
Nonviolent activists counter that the ability of one person to disrupt an assembly is a sign of tacit acceptance by all those who remain silent and do not stop the disruptive one. No one rising up to stop the coup was a sign that Nkrumah's rule was largely unpopular.

Nkrumah's "personal ruling style" was autocratic. Would his policies have succeeded if he had adopted a different ruling style? His underlying political philosophies were also conflicted. While he adopted the Gandhian techniques of positive action advocated by the Fifth Pan-African Congress, Marxism also greatly influenced his thinking.

Marx held that rule by force is necessary because those in power will not willingly give up their power in deference to moral arguments, for example. Likewise, a need exists for a "vanguard"- those politically educated intellectuals who can better understand the true interests of the masses, since the proletarians (in this case, the peasants) might have an erroneous idea of what is in their best interest.

Seeing himself as an enlightened "vanguard," deciding to use force on his people, for their own good, was an easy step to take. ${ }^{28}$ Earlier gains that resulted from working with the people nonviolently for change could appear cumbersome, especially when reaching agreement on a wide range of issues no longer looks easy. Getting the people to do things by force and coercion, as did the colonial government before, could appear to be a productive shortcut.

Nkrumah comes across as someone in a hurry to bring the gains of socialism and independence to his people. He later suggested that gaining independence nonviolently may have been a drawback. He conjectured that had they won independence by armed struggle, they could have established socialism immediately. ${ }^{29}$

But to imagine that violence would have been a better foundation for socialism may be unrealistic. In some cases (Ethiopia, for example), socialist governments founded in violence have not always worked well. The issues are complicated; many books have been written on the topic. We cannot easily resolve the issues here. For our purposes, we see that Nkrumah, looking over the years of his rule and his eventual ousting and exile, was quicker to doubt his use of nonviolence than his use of coercion and violence. In his later book, Handbook for Revolutionary Warfare, he called war logical and inevitable. He claimed that in Africa there was no alternative. ${ }^{30}$

Sutherland recounted his objection to Nkrumah's Preventive Detention Law instituted in 1960. He wrote Nkrumah a confidential letter outlining why he thought the policy was wrong. Soon afterward, Nkrumah's Secretary of Home Affairs, Krobo Edusi, told Sutherland he was lucky that Nkrumah did not have him deported immediately. Edusi warned Sutherland not to bother the president with such matters in the future. He was not deported, but the incident encouraged him to think of leaving. He packed his bags and set off for Tanganyika (later Tanzania). As he explained, with 
his desire to spread the knowledge of techniques of nonviolent action to other parts of Africa, he was drawn to both Nyerere and Kaunda. ${ }^{31}$

\section{Julius Nyerere}

Present-day Tanzania was earlier called German East Africa on the mainland, later to be called Tanganyika when it became a British League of Nations mandate in 1920. In 1946 it became a United Nations Trust Territory under British administration. Zanzibar, the island off the coast of the mainland, became a British protectorate in 1890. Each got its independence separately from Britain, the former in 1961 and the latter in 1963. In 1964 they joined together to create Tanzania. Originally colonized by Germany, Africans rose up against their colonizers in the Maji Maji Rebellion in 1905-1906, in which 120,000 people were killed through fighting or starvation. In 1914-1916, the British fought and captured the mainland territory from the Germans.

Julius Nyerere, a schoolteacher educated at Makerere University in Uganda, was involved in the creation of Tanganyika African National Union (TANU) and the movement for self-government in Tanganyika since the early 1950s. During this struggle, he had traveled to Britain to forge working relations with the British Labour Party. He also went to the United States to speak before the United Nations and to meet with the Maryknoll Fathers, with whom he shared many ideals. Nyerere believed Tanganyika received independence without fighting because there were few white settlers in the country and it was economically underdeveloped. ${ }^{32}$ Luckily he received cooperation from the last British governor of Tanganyika, Sir Richard Turnbull. Mark K. Smith argues that "Nyerere's integrity, ability as a political orator and organizer, and readiness to work with different groupings was a significant factor in independence being achieved without bloodshed." 33 He became prime minister of independent Tanganyika in 1961, a position from which he quickly resigned, and then was elected president in 1962.

While Nyerere has been widely respected throughout his long career, he has upheld certain restrictive legal aspects of the Tanzanian government similar to those in Nkrumah's Ghana, such as the use of preventive detention, creation of a one-party state, and the broadening of the powers of the president. John Hatch noted that some journalists speculated the reason Nyerere so soon stepped down from the position of prime minister was to avoid direct responsibility for the soon-passed Preventive Detention Act and the banning of unions. Nyerere always defended the new government's actions, even when he was not the one in charge. ${ }^{34}$

In his speeches and writings, Nyerere emphasized the values of peace, freedom, and unity. While violence might be able to destroy the old colonial system, it could not build up the new free society. While Nyerere did not hold a strict nonviolent position, he did claim that violence should only be used as a last resort. ${ }^{35}$ In an interview with Sutherland and Meyer just prior to his death, Nyerere explained that although he is a Christian, he could never agree with "Do not kill, full stop." 36 People sometimes have no choice but to use violence against an oppressive state. $\mathrm{He}$ 
explained that his own stand on nonviolence was not "philosophical" but merely practical. He reflected that his reputation as an advocate of nonviolence might have been built during the time of the Mau Mau uprising in Kenya. He tried to encourage Tanganyikans to renounce violence in their independence movement. But he could not insist that all hold the same position regardless of circumstances. He described the context of Africa in the 1950s and 1960s as a continent manipulated by superpowers in a Cold War. Success of the independence movement was the most important goal. Any violence happening in South Africa, for example, was the fault of the apartheid regime, not the liberation movement. The extent of depending on violence as a tactic differed from country to country. The African National Congress (ANC) had an extensive political network; their violent actions were more like propaganda-meant to send a serious message but not capable of military victory. But in Mozambique and Angola, armed movements such as the Liberation Front of Mozambique (FRELIMO) and the Popular Movement for the Liberation of Angola (MPLA) had little or no political structure or communications capability. They were only an army; so only military means were available to them. To give up the option of violence would be to completely dismantle the only existing movement for liberation. But the Tanzanian opportunity for liberation was different, and he explained: "I didn't want bloodshed for nothing, because it was possible for us without it." 37

Nyerere impressed nonviolent activists with his statements upon Tanganyika's independence, which came in the context of a growing arms race between the superpowers. He said disarmament would be a good thing. He also stated that his country and many countries in Africa were not armed. To set an example for the superpowers, he suggested that newly independent African countries should not arm themselves. After all, why would they need an army? Their immediate neighbors were not planning on attacking them.

In 1964, when Tanzania had only about 2000 armed soldiers, some of the soldiers in the Calito barracks on the outskirts of Dar es Saalam decided to mutiny. They were protesting serving under British officers, and wanted better pay. More labor dispute than an attempted coup or protest against the government, the soldiers still were armed and dangerous. They marched on Nyerere's residence. He wanted to reason with them, but his wife and aides insisted he flee. After all, at this time, many coup attempts on African leaders were occurring. Nyerere finally called the British to request help. As Hatch describes the scenario, "This contravened every belief he had fought for, affronted every instinct, and gave him a deep sense of shame he could not assuage for many months." 38

Tanzanians saw their government as quite weak if a handful of soldiers could challenge it so easily. After the British forces handled the situation, Nyerere asked if the British troops in Tanzania could be replaced with African soldiers. Nigerian soldiers (who were still part of the British army) took over the duties of the white British soldiers. Subsequently, Nyerere decided he must train a new defense force. He ensured that a significant part of their training was political education so that they 
would understand and uphold the ethics and objectives of their government. This experience convinced him of the necessity of armed forces for any State. He sent his own sons to China to do military training. ${ }^{39}$

Nyerere supported guerrilla fighting against Portugese colonizers in Angola and Mozambique, practically bankrupting Tanzania in the process. He also supported the toppling of the regime in Comoros in 1975, and in Seychelles in 1977. Idi Amin's Ugandan forces attacked Tanzania in 1978, in retaliation for Tanzania supporting groups hostile to his regime. It took the Tanzanians months to mobilize their troops, but when they finally did, they drove the Ugandan forces out of Tanzania, and then 12,000 of their troops occupied part of Uganda. The Organization of African Unity condemned Tanzania for the foray into a foreign country. ${ }^{40}$ Needless to say, while these military adventures were far from his earlier nonviolent approach, he was loved across Africa for his devotion to the cause of liberation.

Nyerere disagreed with Sutherland's criticism of Nkrumah's use of preventive detention. He claimed that Tanzania needed the same kind of laws. He reasoned that while they should prevent torture and abusive situations in detention, defending the security of the nation is necessary. Preventive detention is justified because community comes before individual rights. He argued that

African countries are no different from many other states: courts are significant, but "when the security of the nation is threatened, the court system is not enough." 41 This recent expression in Nyerere's interview with Sutherland is the same as his 1964 speech at the University College of Dar es Saalam. Then he argued that the Preventive Detention Law was "an inevitable part of my responsibilities of President of the Republic."While he retained defending the rights and freedoms of each individual as a worthy ideal, he argued, "our ideals must guide us, not blind us." 42

Let us look at the details of Tanzania's situation that appear to have led Nyerere to conclude he had no choice other than preventive detention. Reginald Herbold Green explains that under Nyerere's rule and even up to the 1990s, the effectiveness of the rule of law in Tanzania was limited. Lower courts were often incompetent. Participation in the courts was expensive. Local people often could not understand what went on in the court. Revisions to law were slowly and sporadically recorded and implemented. The police and prosecutors were under-funded, understaffed, and often lack expertise. Under such circumstances, investigations and prosecutions were of poor quality. Because of this, "the government has not infrequently lost cases with significant political overtones." "43

A 1978 Amnesty International report said that "Indefinite detention without trial continues to be the means favored by the [Tanzanian] Government to deal with any alleged offence (including corruption) when it fears that it has insufficient evidence for a trial." ${ }^{\prime 4}$ Nyerere thought of preventive detention as unfortunate, but better than alternatives like rigging trials, or suffering a coup perpetrated by unstoppable opponents. ${ }^{45}$ 
How did Tanganyika and Zanzibar legislate and practice preventive detention? James S. Read outlines several laws that allowed the Executive to detain persons without judicial intervention. One was part of the colonial legacy, called the Deportation Ordinance of 1921. To combat growing nationalism in its colony, the government could restrict the movement of a subject to a small area-in effect, detaining them. It provided an early model for the later Preventive Detention Act, instituted one year after independence. With this new act, the government gained the ability to detain anyone without charges secretly and for any length of time. The act gave the president very broad powers. Based on mere subjective factors, he can decide to detain anyone he suspects will breach peace and good order, or who might jeopardize the defense and security of the State. ${ }^{46}$

Under the Refugees Control Act of 1966, refugees had even fewer rights than Tanzanians under the Preventive Detention Act. A government minister had the power to detain refugees that were believed to be harming Tanzania's relationship with another government. The act also allowed detention of any refugee whom the government thought had probably committed a crime in another country. The refugee had no chance for legal defense, did not have to be guilty beyond a reasonable doubt, and the government had no duty to state the reason for the detention.

The Political Officers' Power of Arrest allowed regional and area commissioners to detain suspects for up to forty-eight hours while they awaited appearance before a magistrate. Zanzibar, which had internal self-rule, drafted its own Preventive Detention Decree the year after Tanginyika, in $1964 .{ }^{47}$

To what use were preventive detention laws put during Nyerere's presidency? According to Read, Tanzania drafted the Preventive Detention Law to deal with a developing confrontation with trade unions. The government worried that strikes by workers would hurt the national economy. During Nyerere's presidency, estimates of the number of people detained were in the thousands. In 1977, Amnesty International knew the names of 141 known political detainees. ${ }^{48}$

Under the Refugee Act — which amounted to legal abuse-leaders of liberation movements in other countries were encouraged to bring their prisoners to Tanzania to be held in custody. In 1978, Nyerere finally ordered the release "of twenty members of South African liberation movements, including eleven [South West African People's Organization] SWAPO members who had been arrested in Zambia (where detainees are protected by justifiable constitutional guarantees) and transferred to Tanzania. Some of these had been detained for up to seven years." Read suggests that the most unfortunate aspect of the act was the impression it created that "personal liberty was at the disposal of the authorities, to be granted or withheld at will, rather than a basic right enjoyed by every individual." 49 People were at the mercy of those who might be acting out of jealousy or revenge. Not all cases of detention appear justifiable.

Read does credit Nyerere with keeping the ideal of rights and freedom alive in people's minds, even during all the years that he claimed the practical necessity of 
overriding those rights. Tanzania amended the Preventive Detention Act in 1985 to strengthen the rights of detainees, although it still fell short on several key issues. In Nyerere's last term of office, the Tanzanian people finally passed a Bill of Rights that provided them legal defense. ${ }^{50}$

Nyerere also advocated one-party rule for Tanzania, run by his party, TANU. As he explained, his party was based on equality, respect, freedom, and unity, all of which would be of great service to Tanzanians - so how could he allow opposition to those principles? ${ }^{51}$

In the beginning, Tanganyika was de facto one-party, since voters cast 1,127,978 votes for Nyerere compared to Zuberi Mtemvu's 21,276 votes. By the 1965 elections, the constitution supported a one-party system. Nyerere espoused his rationale that one party could reach out to the people and widen citizen participation so that a narrow group of professional politicians would not win the elected seats. Subsequently, voter participation rose from less than twenty-five percent in 1961 to over seventy-five percent in $1965 .^{52}$

Still, not all Tanzanians were happy with a one-party government. Aikael N. Kweka explained that in this context offering criticism of the way things were done was difficult, since criticism was considered disloyalty to TANU. Nyerere emphasized that although there would be only one party, people should feel free to express their opinions, even criticizing the government. But in 1965, two Ministers of Parliament were expelled from the party for criticizing it and they lost their seats in Parliament. This harsh treatment sent a message to other politicians. The problem, Kweka explains, is, "Although the people were told that they were free to criticize, they did not know when this would be taken for opposition or even considered harmful to the State. ${ }^{, 53}$ Because of these practices, some people experienced the Party as oppressive and undemocratic.

Nyerere repeatedly emphasized the importance of democracy, but he thought that socialism had to alleviate dire poverty and bring about a certain level of economic equality before democracy could have any genuine meaning. As Green explained, hunger and never-ending work schedules robbed many people of experiencing other freedoms enshrined in the concepts of human rights. ${ }^{54}$

While apparently putting rights on the back burner, Nyerere appeared to want to include grassroots participation in decision making regarding economic development. He often (although not consistently) emphasized decentralization of decision making to local communities.

In his political leadership, Nyerere did not insist on self-importance. He wanted to be treated as an ordinary person and not a master over others. He insisted that leaders should not be arrogant or oppressive.$^{55}$ His position on one-party states, he explained, was flexible. By 1986, he realized that the oneparty style of government in Tanzania was doing more harm than good, and that TANU needed to be shaken up and jolted into taking responsibility and doing a good job or risk being voted out by a rival 
party. ${ }^{56}$ In 1990, he stated that suggesting multi-party democracy in Tanzania would not treasonous. The one-party system had been a historical necessity, but that could change. He set up a presidential commission and drew up a list of shortcomings of one-party democracy. Based on this, Parliament passed the Eighth Constitutional Amendment in 1992, allowing multiple parties. ${ }^{57}$

Nyerere believed that coercion, as part of the responsibility of running a state, is unavoidable. Green summarized Nyerere's position, “A legitimate State having reached a decision by legitimate methods has the duty as well as the right to enforce that decision." 58 A famous example was his compulsory relocation of people into villages so that all would have access to education and health facilities.

Nyerere also defended his earlier idea that Africa should take the socialist road to development, through ujamaa (familyhood, emphasizing community and cooperative crop growing) villages. Under capitalism, he explained, Africa would always be a junior partner, dependent on foreign investment. He believed socialism to be more consistent with African values, although to choose it in the contemporary global context would not be easy. While Nyerere did force people to move, he did not coerce them to produce communally. There were incentives to do so but no legal penalties for not doing so. ${ }^{59}$ Sutherland offers his analysis, that bureaucrats working in the Tanzanian government stifled the ujamaa villages. We can imagine the frustration that Sutherland and others felt when they saw functionaries crush a good idea that enjoyed popular support. ${ }^{60}$

Tanzania appeared to represent a chance for a socialist alternative to capitalist development voted in freely and led by a wise statesman. Unfortunately, those who either did not agree with the ideals of the new movement or could not set aside selfinterest to give the ideals a chance bogged down the project on intermediate levels.

It seems to this writer that Nyerere wanted to uphold the ideal of rights while allowing the flexibility to ignore rights when he deemed necessary. Immanuel Kant warned against this self-serving position on morality. He cautioned us about people who wanted others to uphold moral laws while exempting themselves. ${ }^{61}$ It is interesting that, despite Nyerere's practices of preventive detention, he is popularly thought of as a great supporter of human rights, perhaps because of the role he played in the mid-1990s in trying to stop ethnic persecution in Burundi. Upon Nyerere's death in 1999, an obituary noted, "Although he was harsh with his critics and detained some indefinitely without trial, Nyerere never acquired notoriety for human rights abuses." 62 There are, however, a few critics: Smith notes that "There does appear to have been a disjucture between his commitment to human rights on the world stage, and his actions at home." ${ }^{63}$ Nyerere's bold and confident statements regarding justifying his practice of preventive detention seem to point to little or no selfrecrimination on his part.

Nyerere's turn from nonviolence to violence was perhaps not that difficult for him because he hadn't embraced nonviolence in a creedal, Gandhian way in the first place. His Christian background could just as well support a "just war" approach, and in fact 
liberation theology was influencing Catholicism at that time. Nyerere's support of noble causes, the "underdogs" against racist colonial government as well as homegrown dictators like Amin, were easy candidates for just wars. However, Kaunda's version of Christian thought brought him closer to Gandhian nonviolence, and so for Kaunda, the move from nonviolence to violence was more filled with selfquestioning.

\section{Kenneth Kaunda}

Kenneth Kaunda of Northern Rhodesia (now Zambia) was one of the most outspoken supporters of nonviolent action. He was first introduced to Mahatma Gandhi's writings by Rambhai Patel, a storekeeper in Lusaka. He described Gandhi's method of satyagraha as "a lifebelt thrust into the hand of a drowning man." ${ }^{64}$ In 1954, police searched his house and arrested him for having banned publications authored by Gandhi and Jawaharlal Nehru. He spent two months in prison. In 1958, he visited India. When, in 1963, he received an honorary degree from Fordham University in the midst of the struggle for his country's independence, he gave a great tribute to Gandhi and predicted that, like Gandhi, they would wear the British down until they finally got what they wanted. Throughout the struggle, Kaunda endorsed nonviolence and spoke against racialism. He told people not to attack white settlers. He hoped to win over white voters so that they would support him in a nonracial movement. He based his philosophy on Christianity, which he argued showed that Africans were human beings like anyone else. Despite these seeming assurances, the British increased security, suspecting that people could interpret his remarks as condoning attacks against material possessions such as railways, roads, and bridges. ${ }^{65}$

The context in Northern Rhodesia was quite different from Tanzania. Many white settlers in Rhodesia were fighting against colonial rule. Fearing that white settler rule would be harsher than the British rule, Kaunda and his group opposed federation with Southern Rhodesia and insisted on remaining as a colony until the British would give the African majority self-rule. Kaunda was first involved with the Zambia Congress (ZANC) and worked with Harry Nkumbula. Later, while Kaunda and others were in jail, ZANC was banned. Other opposition groups joined together and founded the United National Independence Party (UNIP), which Kaunda headed upon his release from jail. They finally won independence in $1964 .^{66}$

Insisting on nonviolent discipline was not easy. Colin Legum comments that Kaunda's staunch nonviolent stand is particularly amazing, considering that Algerians had already won their independence using violence, and South Africa, Zambia's near neighbor, had rejected strict nonviolence in their own struggle in 1962. Legum was also concerned that the mood of angry frustration among Zambians made the nonviolent Kaunda an unlikely leader. ${ }^{67}$ Kaunda himself clarified that he thought some countries, like those African colonies ruled by Portugal, may have no option but to turn to violence, but that in his own country, it was still possible to reach the rulers with a conscience. He also iterated that the capabilities of nonviolence were still 
largely undiscovered and that he estimated it was a method of great potential. On the level of propaganda, he admitted calculatedly, it is important not to lose the moral advantage which one receives by being the injured party. In the meantime he admitted that his own and others' attempts to be nonviolent would be necessarily imperfect. He often admitted that officers of UNIP had been convicted of rioting, murder, assaults on the police and incitement to violence, but he never condoned this violence. Kaunda often cautioned that inability to get political progress constitutionally would put more pressure on his own people to turn to violence. Reflecting later on this early stage of the struggle, he noted that nonviolence works especially well if it is contrasted to immanent or existing violence, and he admits that he played the role of the rational alternative to the more violent movements in Zambia. ${ }^{68}$

In May 1959 a white woman, Mrs. Lilian Burton, was brutally killed in Zambia, and in response, the colonial government banned UNIP. The British blamed UNIP for an inability to control the people. But Kaunda, who was then in London, told the press that he regretted the attack and wanted to continue to persuade his people to stick to nonviolent discipline. He wrote a letter to family member Robert Burton in which he reiterated that love is a superior force and hate should be eschewed. A few weeks later he met with Robert Burton and other family members in London. Roy Welensky argued that Colonial Secretary Iain Macleod realized he needed to work with the nonviolent Kaunda, as an alternative to those who wanted to "shoot" their way to independence, and met with him in London that month. When Kaunda returned to Zambia he found that European settlers were engaged in a counter-terror response, with "hooligans" meting out punishment to random Africans. Kaunda denounced this reciprocal violence as well. ${ }^{69}$

Kaunda went on a 3,000 mile pilgrimage across Zambia, preaching nonviolence. Historian Fergus MacPherson explains that many Zambians "were explicit in the view that they 'liked' Kaunda's leadership 'because there was no bloodshed in his way of fighting for our freedom." 70 Zambians called their campaign for freedom "Cha Cha Cha" meaning, in rough translation, "face the music." 71 They had huge bonfires of African Identification Certificates, reminiscent of Gandhi's earlier burning of passes in South Africa. Not all Zambians could maintain nonviolence in the face of fierce provocation by government troops and police excesses. Up to Kaunda's arrival in London to negotiate independence, he continued to appeal to those in his country to stop "stonings, assaults, unlawful assembly, riot, arson, murder, unlawful wounding and obstruction of the police." 72

North Rhodesia had its first African party government in the January 1964 elections. During the campaigning, Kaunda had repeatedly preached against violent retaliation against whites. Just after the elections, he found his party and African rule attacked by a small group that rejected African nationalism and supported continuation of colonial rule. The Lumpa sect, which followed the prophetess, Alice Lenshina, was a local offshoot of Christianity based in Kaunda's home district, Chinsali. Followers refused to obey the government and were hostile toward UNIP. 
They built stockades around their villages and terrorized their neighbors. In the battles that ensued from July-October 1964, 700-1,500 people lost their lives. ${ }^{73}$

What caused the Lumpa to rise up and fight UNIP? In the 1950s, the Lumpa were favorable to nationalism, but that changed by 1957 . Nationalism focused on peasants, unlike the proletarians who flocked to UNIP. Andrew Roberts said UNIP had become a way of life, central to members' identity. The members generally followed mainstream Christianity, so the increasing membership threatened the Lumpa religion. Wim van Binsbergen speculated that the Lumpa leadership benefited from colonial relations. They did not want Africans to rule them. Robert Kaunda, a deacon in the Lumpa church, went further and charged that agents of Welensky's United Federal Party offered Alice Lenshina 8,000 pounds to break with UNIP, which she reluctantly accepted. This was interpreted as an attempt by Kaunda's enemies to use the Lumpa to derail the new government. Lenshina warned her followers not to register to vote or hold a party card. They were advised not to honor the Zambian flag or national anthem. By 1964, they had forbidden their children to attend school and they barricaded themselves in their villages. Because the Lumpa opposed UNIP they were seen not only as political opponents of Kaunda but even as "enemies of the nation." 74

Although Kaunda agonized over the use of force against Lumpa intransigence and uprising, he continued the state of emergency started by the governor of Rhodesia up to 1972. MacPherson notes that "the baleful irony of the situation was that Governor Hone had to invoke, against the Lumpa sect, Emergency powers first enacted in the Preservation of Public Security Ordinance by a virtually white Legislature to counter Kaunda's movement for national sovereignty." 75 Kaunda spoke on a radio broadcast and made a statement to the National Assembly explaining that "we are dealing with a completely fanatical sect whose members are not only prepared to die for their faith and consider it a passport to Heaven to do so, but who are also prepared to kill as many other people as they can before they die themselves." ${ }^{\prime 76}$ He justified his use of force afterward, in many speeches suggesting that the Lumpa sect was engaged in sorcery and that his government was moral and Christian. In contrast to Kaunda's militaristic approach, van Binsbergen thought that the country needed reconciliation between UNIP and the Lumpa. That happened slowly, culminating when their prophetess, who had been imprisoned, was finally released in $1975 .{ }^{77}$

The Lumpa sect, and another called the "Watchtower," which also rejected the new African-run state, comprised only five percent of the population. Could the new government allow them to question its authority? In addition, their small number made them an easy military target and the nature of their beliefs may have led Kaunda to believe that he could not reason with them. Were those two factors part of the true cause of his switch to violent methods?

Kaunda seems quite reflective about the way in which he was forced, while in office, to change from the believer in nonviolence who challenges a government in power, to that of a head of state in charge of a military. He wrote The Riddle of Violence on the subject, published in 1980. In it he describes the dilemma of a ruler. 
He described the strange feeling when one enters government for the first time, which seems like a new world. One walks the corridors where one's opponents once resided and worked. When one earlier encouraged people to not pay taxes, one is now in the position of encouraging people to pay taxes. Where one once told people to boycott schools, one is now telling students to attend school. One also sees the "levers of power" under the surface, and one must banish the fond hope that one need not touch them. To stand by and do nothing while a small group arms itself and denies the legitimacy of the new government is not an act of innocence. ${ }^{78} \mathrm{He}$ was pained by his decision to use force, perhaps because, as Arendt would say, conscience is the part of self that realizes through inner reflection the inconsistencies of ideals with each other or between ideals and actions. ${ }^{79}$ As he stated, "If we must even contemplate offering violence to our fellow human beings it is always better to do so against the pressure of an uneasy conscience." 80

Many of Kaunda's statements in The Riddle of Violence show his frustration with his critics (whether external critics or his own conscience) which explains how he had no choice but to use the coercive machinery of the state to defend it against the Lumpa and other internal enemies. He challenges, people can't seriously expect him as Head of State to dismantle the army and police, and empty the prisons. After all, one has to fight evil, it will not just go away of its own accord. Since dialogue alone can't solve all problems, all states must use compulsion and violence. He explains that when they took over the Zambian state from the British, "we climbed on to an escalator already on the move, by which I mean that Zambia like every other state was already caught up in the vicious circle of violence." 81

Sutherland and Meyer had an opportunity to interview Kaunda for Guns and Gandhi. After many years in power in a one-party state, he had been defeated in a multi-party election, where 81 percent of the popular vote went to his opponent, Frederick Chiluba. Kaunda and Sutherland engaged in a lively debate about the continued practicality of nonviolence. Kaunda conceded that Gandhi was a saint, but he, by contrast, had chosen the path of a politician. Sutherland countered that such ideas distort Gandhi's ideas, since Gandhi stated that an individual did not have to be a saint to participate in a nonviolent struggle. Sutherland insisted that nonviolence advocates eschew violence not because they are rigid, but because they are trying to break a cycle of violence. ${ }^{82}$

Kaunda related his ideas on nonviolence to the nature of the state and to human nature. Human beings need the state because they imperfectly love God and their neighbor. Because of their imperfection, they need an authority, which provides the framework of order and justice. Once human beings reach moral and spiritual perfection, they will no longer need police, prisons, and oppressive State machinery. ${ }^{83}$

While Kaunda certainly shows himself to be a reflective and sensitive person, who more than most grappled with the dilemmas of being nonviolent in our current world, his comments in the interview as well as in his book veer from the profound moral quandary, to the seeming excuses for abuses of power. While it may be the case that 
contemporary states cannot realistically give up all means of coercion, there are matters of degree. Not all of Kaunda's decisions seem to be as cautious regarding wielding coercive power as one might hope, given his sensitive conscience.

\section{Conclusion}

Nkrumah, Nyerere, and Kaunda each used nonviolent methods against the armies of the British. Each turned to preventive detention and other repressive measures once in power. Each refashioned their state into a one-party system. Each defended the use of force by the state as a necessity in our current world of nation-states. Nyerere explained, "Once you've accepted the nation-state, you accept the consequencesincluding armies, including security service bureaucracy, police and the lot." 84

Before colonial rule, African chiefs would have counselors and listen to their people. Even people who threatened the safety of the chief were merely fined as a consequence. ${ }^{85}$ After independence, many African governments incarcerated or even killed people for criticizing the president. Is taking "state security" to such extremes part of the inheritance of the European-style nation-state?

Basil Davidson's The Black Man's Burden calls the nation-state a curse put upon Africa. Perhaps the worst part of the curse is inheriting armies that could do the bidding of a president, including trampling on the human rights of the citizens. ${ }^{86}$ But not all nation-states are equal in this trampling. Some nation-states can seriously apply themselves to becoming participatory democracies, decreasing the occasions on which force is used. A system of checks and balances-like an independent and functioning judiciary - can stop the excesses of executive power.

The timing of each leader's turn to coercion and violence warrants further exploration. Each turned to violence in the early months or years of the newly independent state. Possibly each turned to coercion due to a crisis in authority. They each attempted to assert their authority in a context where it questioned or challenged by incorrigibility.

Are all states violent by nature? African heads of state inherited armies, police, courts and jails based on the Western model, but that does not necessarily entail that they would have to accept the use of violence. For Arendt, action, but not violence, is central to all politics. Violence is a sign that political action, based on dialog and consensual agreement, is breaking down. A state, where the public realm thrives and where people can express their diverse views and act politically in concert with each other - is always a good thing. ${ }^{87}$ This model of responsiveness is found in some of the examples cited by Mamdani of chiefs responsible to their communities and listening with open ears to their counselors.

While certainly our three Heads of State would easily agree that working out problems through dialogue and mutual agreement is preferable to violence and coercion, they may state that nevertheless in certain circumstances, nonviolence is a luxury that cannot be afforded. Kaunda insisted that one cannot rely on dialogue 
always solving problems. He knew that Gandhi and nonviolent activists would say that the gains of violence are not long lasting; problems not addressed at their root causes but "solved" quickly through violence will crop up again. But Kaunda built on this metaphor: "War is just like bushclearing - the moment you stop, the jungle comes back even thicker, but for a little while you can plant and grow a crop in the ground you have won at such terrible cost." 88 Such statements suggest that repeated wars and repression are inevitable, but that one should not overlook the small gains in the midst of the wars. Kaunda also argued that while his critics might say that colonial tyranny was merely replaced by African tyranny, he must point out that even that is still a gain - "most people would rather be dragooned by their own kind than by aliens." 89 He cautioned that he did not want his remark to give the impression that he was not opposed to tyranny.

Certainly any time we critique new African states we must keep in comparative context the suffering Africans endured under colonial rule. Our three heads of State also had the challenges of being pioneers of a new situation, in "uncharted waters" so to speak. Even Gandhi had slim experience in ruling a nation nonviolently. When India got its independence, Gandhi bowed out of holding public office. His Indian National Congress took over the military and police. Gandhi wrote about how the police could be redeployed in development projects, and how armies could become superfluous if Indian citizens would organize themselves to repel external aggressors nonviolently. ${ }^{90}$ But these ideas were not implemented, so no one yet knew if they would work. Without an alternative precedent, it is not surprising that the African Statesmen followed the paths that they took. But this points to a need to develop nonviolent strategy to include the neglected later stage of nonviolent statecraft.

Glenn D. Paige is one contemporary political scientist who is exploring what he calls "nonkilling" political science. Paige suggests that states should renounce their usually accepted role as those who both threaten and carry out lethal force to "those who do not conform to public order." 91 It may be difficult for a state to imagine renouncing lethal power since it considers itself to have a duty of providing security. But this transformation of the state can come in stages, and can work progressively in several states at once. He describes an "unfolding fan of nonkilling alternatives" that can begin with high technology interventions in killing zones that reduce fatalities, and go further to include socialization and cultural conditioning for nonviolence, and to restructuring economies and social stratification so that systems do not "require lethality for maintenance." 92 A society which begins by being pro-violent (considering state violence to be beneficial for society) can become ambivalent, and then violenceavoiding ("predisposed not to kill... but prepared to do so" to finally nonviolent (once societal conditions have been changed enough to support a nonviolent structure). ${ }^{93} \mathrm{In}$ order to make these changes, there need to be revolutions in education, institutions, methods and norms. Certainly it is understandable that news Heads of State who inherited state systems that were far from this nonviolent model could not make drastic changes overnight. In the short run, their hands may have been tied by lack of 
concrete alternatives. But such appeals to realism should not preclude seeking the longer-term goal of a nonkilling, nonviolent state.

Gandhi drew a distinction between what he called nonviolence of the strong, and nonviolence of the weak. He feared that India was resisting the British nonviolently because they considered themselves to be weak, having no choice but to be nonviolent since they would fail in use of violence. Gandhi instead wished that the Indian people could realize that they came from a great position of strength, due to their greatly outnumbering the British as well as their coming from a long spiritual heritage. He wanted Indians to have the experience of (psychologically) realizing their strength, and then renouncing this ability to do violence. That would be the nonviolence of the strong. He began to doubt that his comrades in the movement could do so. But one who comes from a position of strength, and then renounces violence, has an experience of self-discipline that eludes the weak person.$^{94}$ It is similar to what Sara Ruddick describes as a mother's renunciation of using violence against her own recalcitrant child; she will not use her own size and psychological strength advantage against the child but rather restrains her superior power, modeling what Ruddick thinks is a helpful model for nonviolence in the political sphere. ${ }^{95}$ We could specula99te that, if during their fights for independence, our three Heads of State had more experiences of practicing "nonviolence of the strong," they could have more easily resisted the temptations to use their strength advantage of their new position to the detriment of their opponents.

\section{Notes}

1. Bill Sutherland and Matt Meyer, Guns and Gandhi in Africa: Pan-African Insights on Nonviolence, Armed Struggle, and Liberation in Africa, Foreword by Archbishop Desmond Tutu (Trenton, N.J.: Africa World Press, 2000).

2. Henry L. Bretton, The Rise and Fall of Kwame Nkrumah: A Study of Personal Rule in Africa (New York: Frederick A. Praeger, 1966), pp. 13, 15.

3. Basil Davidson, The Black Man's Burden: Africa and the Curse of the Nation-State (London: James Currey, 1992), pp. 173-181, 208.

4. Mahmood Mamdani, Citizen and Subject: Contemporary Africa and the Legacy of Late Colonialism (London: James Currey, 1996), pp. 41, 53-63.

5. Ibid., pp. 44-45.

6. Gene Sharp, The Politics of Nonviolent Action, Volume 1: Power and Struggle (Boston: Porter Sargent, 1973), pp. 7-62.

7. Hannah Arendt, Crises of the Republic (New York: Harcourt, Brace, Jovanovich, 1972), pp. 140-143, 152-155; and "Hannah Arendt on Power," Philosophical Perspectives on Power and Domination: Theory and Practice, eds. Laura Duhan Kaplan and Laurence F. Bove (Amsterdam: Rodopi Press, 1998), 29-40.

8. Hannah Arendt, Between Past and Future: Eight Exercises in Political Thought (New York: Penguin, 1985), p. 229. 
9. Ibid., p. 25; and Kwame Nkrumah, Ghana: The Autobiography of Kwame Nkrumah (New York: International Publishers, 1957/1971), pp. 52-53.

10. Interviews with Geoffrey Adumah and Komla Gbedema, Freedom Now: 1947-1990, PBS

"People's Century" series <http://www.pbs.org/wgbh/peoplescentury/

episodes/freedomnow/aduamahtranscript.html> and <http://www.pbs.org/wgbh/people scentury/episodes/freedomnow/gbedematranscript.html .

11. Nkrumah, Ghana, pp. 103, 111, 114; and quote from Sutherland and Meyer, Guns and Gandhi, p. 30.

12. Nkrumah, Ghana, p. 116; and Joan Bondurant, Conquest of Violence: The Gandhian Philosophy of Conflict (Berkeley: University of California Press, 1967).

13. Nkrumah, Ghana, pp. 117-119; and Sutherland and Meyer, Guns and Gandhi, p. 31.

14. Ibid., pp. 121, 124, 164.

15. Sutherland and Meyer, Guns and Gandhi, p. 31.

16. Sutherland and Meyer, Guns and Gandhi, pp. 4-6.

17. Ibid., pp. 36-41.

18. Ibid., p. 42.

19. Marika Sherwood, "Kwame Nkrumah: The Father of African Nationalism, by David Birmingham," (book review), International Journal of African Historical Studies, 32:1 (1999), pp. 151-152.

20. Ibid.

21. Ibid.

22. Kwame Nkrumah, Dark Days in Ghana (New York: International Publishers, 1969), pp. 49-50, 83, 91, 95-96.

23. Davidson, The Black Man's Burden, pp. 103-105.

24. Nkrumah, Dark Days in Ghana, pp. 48, 57.

25. David P. Johnson, "Nkrumah, Kwame," Africana: Encyclopedia of African and African American Experience, eds. K. Anthony Appiah and Henry Louis Gates (Basic Books, 1999), p. 1441.

26. Nkrumah, Dark Days in Ghana, pp. 63-64, 67.

27. Ibid., pp. 29-30, 44-45.

28. Bretton, The Rise and Fall of Kwame Nkrumah, pp. 61, 84.

29. Nkrumah, Dark Days in Ghana, p. 71.

30. Sutherland and Meyer, Guns and Gandhi, p. 48.

31. Ibid., p. 63.

32. John Hatch, Two African Statesmen: Kaunda of Zambia and Nyerere of Tanzania

(Chicago: Henry Regnery Company, 1976), pp.111, 143.

33. Mark K. Smith, "Julius Nyerere, Lifelong Learning, and Informal Education." Infed

Encyclopedia, (2005) http://www.infed.org/thinkers/et-nye.htm.

34. Hatch, Two African Statesmen, pp. 179-80.

35. Aikael N. Kweka, "One-Party Democracy and the Multi-Party State," Mwalimu: The

Influence of Nyerere, eds. Colin Legum and Geoffrey R. V. Mmari (London: Britain-

Tanzania Society/James Currey, 1995), p. 61-79, esp. p. 73.

36. Sutherland and Meyer, Guns and Gandhi, p. 83.

37. Ibid., pp. 82-83.

38. Hatch, Two African Statesmen, pp. 145, 200.

39. Ibid., pp. 201, 253-254, 259. 
40. “Tanzania," Africanet Online Encyclopedia <http://www.africanet.com/afri

canet/country/tanzania/history.htm>.

41. Sutherland and Meyer, Guns and Gandhi, pp. 86-88, citation p. 87.

42. James S. Read, "Human Rights in Tanzania," Mwalimu, pp. 138-139.

43. Reginald Herbold Green, "Vision of Human-Centred Development: A Study in Moral

Economy," Mwalimu, pp. 80-107, citation, p. 95.

44. Read, "Human Rights in Tanzania," p. 140.

45. Green, "Vision of Human-Centred Development," p. 95.

46. Read, "Human Rights in Tanzania," pp. 137-138.

47. Ibid., pp. 141, 143.

48. Ibid., p. 137, 149.

49. Ibid., p. 143 and 139 respectively.

50. Ibid., pp. 141, 144.

51. Kweka, "One-Party Democracy and the Multi-Party State," p. 69.

52. Hatch, Two African Statesmen, p. 186.

53. Kweka, "One-Party Democracy and the Multi-Party State," pp. 68, 71.

54. Ibid., p. 72; and Green, "Vision of Human-Centred Development," p. 80.

55. Kweka, "One-Party Democracy and the Multi-Party State," pp. 72, 74; Green, "Vision of

Human-Centred Development," pp. 86-91; and Hatch, Two African Statesmen, p. 198.

56. Green, "Vision of Human-Centred Development," pp. 84-85, 94-95.

57. Kweka, "One-Party Democracy and the Multi-Party State," pp. 75-77.

58. Green, "Vision of Human-Centred Development," p. 91.

59. Ibid., p. 92.

60. Sutherland and Meyer, Guns and Gandhi, pp. 89, 91-92.

61. Immanuel Kant, Groundwork of the Metaphysic of Morals (New York: Harper

Torchbooks, 1956), p. 91.

62. Rodrique Ngowi, "Father of Tanzania Dies at Age 77," Associated Press, Oct. 14, 1999

<http://www.anc.za/ancdocs/history/people/nyerere/newsart.html>.

63. Smith, "Julius Nyerere."

64. Kenneth Kaunda, The Riddle of Violence, ed. Colin Morris, (San Francisco: Harper \&

Row, 1980), pp. 15, 18, citation 18.

65. Hatch, Two African Statesmen, pp. 63, 78, 152, 167, 170, 173, 238.

66. Ibid., pp. 61, 161.

67. Colin Legum, ed., "Introduction," Zambai, Independence, and Beyond: The Speeches of

Kenneth Kaunda (London: Thomas Nelson and Sons, 1966), p. xii.

68. Fergus MacPherson, Kenneth Kaunda of Zambia: The Times and the Man (Lusaka:

Oxford University Press, 1974), pp. 309-11; and The Riddle of Violence, pp. 35, 51-52.

69. MacPherson, Kenneth Kaunda, pp. 312-315.

70. Ibid., pp. 350-51.

71. Ibid., p. 145.

72. Ibid., p. 351; citation p. 411.

73. Hatch, Two African Statesmen, p. 176; and Wim van Binsbergen, "Religious Innovation and Political Conflict in Zambia: A Contribution to the Interpretation of the Lumpa Rising," Religious Innovation in Modern Africa Society, eds. van Binsbergen and Robert Buijtenhuijs (Leiden: Afrika-Studiecentrum, 1976); revised reprint in van Binsbregen, Religious Change in Zambia: Exploratory Studies (London/Boston: Kegan Paul International, 1981). 
74. MacPherson, Kenneth Kaunda, pp. 410-411.

75. Ibid., p. 443.

76. Ibid.

77. van Binsbergen, "Religious Innovation and Political Conflict in Zambia."

78. Kaunda, The Riddle of Violence, pp. 36-38.

79. Hannah Arendt, The Life of the Mind, Vol. 2: Willing (New York: Harcourt Brace Jovanovich, pp. 185-186).

80. Kaunda, The Riddle of Violence, p. 179.

81. Ibid., pp. 24, 41-42, 62, 137, citation p. 42.

82. Sutherland and Meyer, Guns and Gandhi, p. 101.

83. Hatch, Two African Statesmen, p 246.

84. Sutherland and Meyer, Guns and Gandhi, p. 87.

85. Mamdani, Citizen and Subject, pp. 44-45.

86. Davidson, The Black Man's Burden, p. 208.

87. Hannah Arendt, Collected Papers, vol. 64 (Washington, D.C.: Library of Congress, 1968), pp. 014368-014369; Arendt, Crises of the Republic, pp. 140-43, 152-55.

88. Kaunda, The Riddle of Violence, p. 78.

89. Ibid., p. 79.

90. Mohandas K. Gandhi, The Collected Works of Mahatma Gandhi (New Delhi: Government of India Ministry of Information and Broadcasting, 1988), 48:417-420 (10 December 1931);

Mohandas K. Gandhi, The Essential Writings of Mahatma Gandhi, ed. Ragavan Iyer (New Delhi: Onford India Paperback, 1993), pp. 264-265.

91. Glenn D. Paige, Nonkilling Global Political Science (New Delhi: Gandhi Media Center, 2002), p. xix.

92. Ibid., p. 78

93. Ibid.

94. Gandhi, The Collected Works, 88:336 (8 July 1947); 88:356 (17 July 17 1947); Gandhi, The Essential Writings, pp. 238-39, 247.

95. Sara Ruddick, Maternal Thinking: Toward a Politics of Peace (Boston: Beacon Press, 1995), pp. 66-68, 166-67. 